\title{
Capital Market Volatility MGARCH Analysis: Evidence from Southeast Asia
}

\author{
Sylva Alif RUSMITA ${ }^{1}$, Lina Nugraha RANI ${ }^{2}$, Putri SWASTIKA ${ }^{3}$, Siti ZULAIKHA ${ }^{4}$
}

Received: August 01, 2020 Revised: September 20, 2020 Accepted: October 05, 2020

\begin{abstract}
This paper is aimed to explore the co-movement capital market in Southeast Asia and analysis the correlation of conventional and Islamic Index in the regional and global equity. This research become necessary to represent the risk on the capital market and measure market performance, as investor considers the volatility before investing. The time series daily data use from April 2012 to April 2020 both conventional and Islamic stock index in Malaysia and Indonesia. This paper examines the dynamics of conditional volatilities and correlations between those markets by using Multivariate Generalized Autoregressive Conditional Heteroscedasticity (MGARCH). Our result shows that conventional or composite index in Malaysia less volatile than Islamic, but on the other hand, both drive correlation movement. The other output captures that Islamic Index in Indonesian capital market more gradual volatilities than the Composite Index that tends to be low in risk so that investors intend to keep the shares. Generally, the result shows a correlation in each country for conventional and the Islamic index. However, Internationally Indonesia and Malaysia composite and Islamic is low correlated. Regionally Indonesia's indices movement looks to be more correlated and it's similar to Malaysian Capital Market counterparts. In the global market distress condition, the diversification portfolio between Indonesia and Malaysia does not give many benefits.
\end{abstract}

Keywords: Financial Times Stock Exchange, Hijra Index, Jakarta Composite Index, Jakarta Islamic Index, Volatility Index

JEL Classification Code: C32, G15, O16

\section{Introduction}

One of the important things that need to be measured in the capital market is the volatilities. The volatilities of capital market represent occasion for any investor to enter the market with the right insight. A volatile market, however, indicates a set of risks inherent within the market. Any cautious investors would be keen to benchmark his/her

${ }^{1}$ First Author and Corresponding Author. Lecturer, Islamic Economics, Faculty of Economics and Business, University of Airlangga, Indonesia [Postal Address: Campus B, Jalan Airlangga No. 4, Surabaya, East Java, 60286, Indonesia] Email: sylvalifr@feb.unair.ac.id

${ }^{2}$ Lecturer, Islamic Economics, Faculty of Economics and Business, University of Airlangga, Indonesia. Email: linanugraha@feb.unair.ac.id

${ }^{3}$ Lecturer, Islamic Economics, Faculty of Economic and Business,

State Institute of Islamic Studies (IAIN) Metro, Indonesia.

Email: swastikaputri@gmail.com

${ }^{4}$ Lecturer, Islamic Economics, Faculty of Economic and Business, University of Airlangga, Indonesia. Email: siti-z@feb.unair.ac.id

(c) Copyright: The Author(s)

This is an Open Access article distributed under the terms of the Creative Commons Attribution Non-Commercial License (https://creativecommons.org/licenses/by-nc/4.0/) which permits unrestricted non-commercial use, distribution, and reproduction in any medium, provided the original work is properly cited. stock's portfolios with market indices, in order to measure their risks as well as forecasting their return.

Decades after its first launch, investors still assume the achievement of Islamic stock index performance are lower than the composite indexes and conventional counterparts. This condition needs to be proved sharply and analysis deeply, whether Islamic stock indexes have ability to generate return portfolio and portfolio performance higher than conventional. It is important to observe the volatility of Islamic index because the investor in Islamic index are majority rational investors whose objectives are looking for ways to secure their assets' value from falling down (Abduh, 2020).

In Southeast Asia, there are two emerging countries that have Islamic capital market; market; that is, Indonesia and Malaysia. Each country has their own rules to screening the stock into Islamic Index, but all of them have similarity which is prohibited non-halal transaction and every capital market provide the different return and performance. In fact, in Indonesia, all Islamic Shares are incorporated in the Indonesia Shariah Stock Index (ISSI), and the screening process is carried out by the National Sharia CouncilIndonesian Ulema Council (DSN-MUI). While in Malaysia, 
the list of sharia shares is incorporated in the FTSE Bursa Malaysia Hijrah Syariah Index (FBMHS), and the selection is determined by the Shariah Advisory Council (SAC). Both DSN-MUI and SAC impose rigid rules which scrutinize the financial statements of listed companies that will enter the Islamic Index or sharia Index. The existing screening process are expected to facilitate investors who are very concerned about the permissibility of the index.

Dewandaru, Rizvi, Masih, Masih, and Alhabshi (2014) mention there are specific features that distinguish the conventional stock and the Islamic stock market. The study shows Shariah-compliant companies are considered, to be more volatile returns. In other words, the Islamic riskier market, because it contains stocks that tend to have higher correlations with the global market return and the company life cycle. Karim, Majid, Isa, and Jais (2010) explain on their study that the diversification of portfolio is limited for investors to gain risk-reduction benefits through diversifying their portfolio between Indonesian, Singapore, and China markets (trading partners).

This study tries to fill the gap in the previous study by analyzing the correlation and volatility of sharia or Islamic index with composite conventional index in Indonesia and Malaysia. This research will examine through capital market indicators. The novelty of this research is providing the updates data with a length on eight years from April 2012 to April 2020, also to extended the knowledge of volatilities in the previous study with case Indonesia and Malaysia. The other novelty is will provide the best diversification choices for investor in Indonesia and Malaysia both local or international. This study applies a robust multivariate GARCH model to address the research inquiry. At the end, the study will give a suggestion for investors, so that they will have new references before they choose to enter the market.

\section{Literature Review}

\subsection{Sharia-compliant Stocks and Islamic Index}

The Islamic Capital Market is known as part of Capital Market, some countries have dual capital market system. In the operational transaction only several things that is different with capital market, there are the screening process of Islamic share and the rules about prohibition non halal transaction. The share which listing in the Islamic capital market mush be screening into several criterion whose items are derived from values and principles prescribed Islam. This process is aimed to separate which stocks that meet with Sharia and which are not, thus making it easier for religious investors to choose (Omar, Abduh, \& Sukmana, 2013). However, in the implementation, some adjustments on the rules and regulations are needed in order to promote and familiarize these screening process to the public.. There are two aspects on the screening process, first is financial screening related to non halal profit. Second is non-financial process or business process, the business process must halal.

Furthermore, stocks that have passed the Sharia screening process will usually be grouped into several indexes. This needs to be done in order to find out the development of the stocks with specific characteristics, as well as to facilitate investors in understanding the performance and characteristics of the stocks that are incorporated in Sharia indexes. Some Islamic indexes that are often used in research are the S\&P Sharia index, the Dow Jones Islamic Index, and the Jakarta Islamic Index. The index is representing certain condition of stock with specific criterion, for example JII represent the most liquid and sharia compliance stock. On the other hands index could reflect the market condition and as benchmark market movement so the foresting of investment both single or portfolio could be predicted. Investor could hedge the risk of volatility based on the information in the index.

The development of sharia index in Indonesia began in 2000 when one of the securities companies, PT. Danareksa Investment Management collaborates with the Indonesia Stock Exchange to launch the Jakarta Islamic Index (JII). This index is presented to facilitate investors who are interested in investing their funds in a Sharia way. JII covers 30 of Indonesia's most liquid Islamic stocks. The liquidity criteria are mainly based on market capitalization and daily transaction value

From the perspective of Malaysia, its Islamic capital market has become a growing focus and this is due to investors, be it individuals or institutional investors, demanding more from their Islamic investments (AlKhazali, Lean, \& Samet, 2014). Looking at the Islamic stock constituents of Malaysia, the scenario is quite apparent. The FBM Emas Index (FBMEI), for instance, consists of 276 stocks and 203 of the total stocks (or 74 per cent) are Shariah-compliant stocks. In 2013, the Shariah-compliant stocks, as reflected by the FBM Emas Shariah Index, had performed better than the overall FBMEI stock.

\subsection{Risk and Return in Investment}

Return is income from investment activity based on the possible risk that faces by investor. The expected return is the possibility income that could motivated investor to invest after comparing with market return. Return on investment can be estimated by estimation market condition and macro-economic fluctuation. Future investment return is expected return and diverse with actual return that received by investors (Alexander \& Baptista, 2003). In managing investment, it is necessary to distinguish between expected return and actual return. On the other hand, to manage the return or get the optimum return investor must have best 
diversification. According to Ajmi, Hammoudeh, Nguyen, and Sarafrazi, (2014) they argue that international portfolio diversification will reduce the risk for the investors, as they tend international investment have low correlation for every county, so the risk could be reduced even though the return also not so high.

Expected return is the return that required by the investor to get higher that the risk-free return, and also to anticipated the high risk in the future. in the future. While, the actual return is the rate of return that has been obtained by investors in the past (Rusmita, Salleh, Sukmaningrum, $\&$ Zulaikha, 2019). The difference between expected return and actual return is a risk that should always be considered in the investment process so that in investing in addition to paying attention to the rate of return investors should always consider the level of risk an investment (Fama, 2017).

The formula of Return as follows:

$$
R_{t}=\ln \left(P_{t}-P_{t-1}\right)
$$

where $\mathrm{R}_{t}=$ daily return; $\mathrm{P}_{t}=$ closing price; $\mathrm{P}_{t-1}=$ closing price at $\mathrm{t}-1$

Risk is a possible realization of actual return smaller than the expected minimum return. Generally the greater the risk, the investor will requiring the greater the level of expected return. An Investor other than trying to avoid the source of a risk, it is also important to calculate the risk of an investment. For the calculation of the level of risk, can use the value of variance and standard deviation. The variance or standard deviation is a large measure of the distribution of random variable data from its mean value. The greater the spread of the return distribution of an investment, the higher the investment risk. The root of the variant (standard deviation) is an estimate of the risk of the stock price, namely:

$$
S=\sqrt{\frac{\sum_{t=1}^{n}\left(R_{t}-\bar{R}_{t}\right)^{2}}{n-1}}
$$

\subsection{Previous Studies}

\subsubsection{Diversification and Market Volatilities}

Tamakoshi and Hamori (2014) and Uddin et al. (2013) had studied the co-movement dynamics between developed Germany and international stock markets and they suggest that the co-movements of the stocks are not constant, and returns are time-varying. Thus, it suggested for researchers to use time-varying conditional correlation models when modeling volatilities and correlations. They mention allocation and risk management was important in designing international portfolios for investment decisions. Besides that, further studies suggest that there is a high possibility that investment holding periods also have impacts on the volatilities and the dynamics of correlations of stock market returns (Gencay, Selcuk, \& Witcher, 2001; In \& Kim, 2013).

There are specific features of difference between the conventional and the Islamic capital market, particularly in the specification of the risk-return profile. In this regard, the screening criteria undertaken by the Islamic investment is based on Shariah principles which exclude non-compliant companies from its pool of investable equities. Thus, only Shariah-compliant companies are considered, resulting in a smaller pool of investable equities with more volatile returns (Dewandaru et al., 2014). Returns which are more volatile usually depict a riskier market because it contains stocks which tend to have higher correlations with the overall market performance and the business cycle.

Worthington and Higgs (2004) held a research in Asia equity markets, in both developed and emerging market, about its equity returns and volatility using MGARCH method, which later exploring the difference between two markets. In results, this research showed a large and predominantly positive mean and volatility spillovers. Nevertheless, mean spillovers from the developed to the emerging markets are not homogenous across the emerging markets, and own-volatility spillovers are generally higher than cross-volatility spillovers for all markets.-

The stock markets' volatility and its correlation between assets return, including their relationship (positive or negative) and size (stronger or weaker) is of crucial importance for both the domestic and international investors with a view to diversifying their portfolios for hedging against unforeseen risks (Saiti, Bacha, and Masih, 2014). Using the MGARCH method, the results concluded that the conventional and Islamic indices in Japan, GCC ex-Saudi, Indonesia, Malaysia, and Taiwan provide better diversification benefits compared to Korea, Hong Kong, China, and Turkey. It suggested that a better diversification benefits is found in Islamic Countries rather than in the Far East countries with strong policy implications for the domestic and international investors in their portfolio diversification for hedging against unforeseen risks.

In the Philippines stock market, exchange rate of Peso to Dollar, London Interbank Offered Bank, and crude oil price affected its volatility, both in the short-run and long-run (Camba, 2020). In long-run, the exchange rate and crude oil price's relationship towards Philippines Stock Market Index (PSEI) was unidirectional, while a bidirectional relationship occurred between London Interbank Offered Bank and PSEI. On the other hands, the research of Rahmi, Azma, Muttaqin, Jazil, \& Rahman (2016) concludes another factors of the market volatility. They stated that both Islamic and conventional index in Indonesia show specific volatility with different causes. Exchange rate and money supply affected Jakarta Islamic Index (JII) while interest rate and exchange rate exert influence on Jakarta Composite Index. 
Kamil, Kamil, Bacha, Ismath, Masih, and Mansur (2012) implied the relationship between volatility of several markets using MGARCH model. Kamil et al. (2012) analyzed the returns and volatility for stocks traded in the Sharia compliance stock on the Islamic Capital Market Malaysia.

To achieve the first research objective, this study measures the volatility of both conventional and Islamic indices using Multivariate Generalized Autoregressive Conditional Heteroscedasticity (MGARCH).

\section{Research Method}

This research utilizes secondary data. The data in the study is daily transaction data from April 2012 to April 2020 and will be taken from each index, such as JCI, JII, FTSE Hijrah, and FTSE, which are the research samples. This data is the closing price of each index collected from historical prices from the Indonesian and Malaysian exchange markets. Daily data is used in order to get a robust result, while the period selection was intended to provide the most recent illustration of the Indonesian and Malaysian market condition.

The Islamic indexes and composite use on this research they are; first the Jakarta Composite Index (JCI) is used as a proxy in measuring market risk in the stock price analysis model. The JCI reflects the movement of daily stock price changes of all shares listed on the Indonesia Stock Exchange (Gumanti, 2011). Second, the Jakarta Islamic Index (JII) is one of the stock indices in Indonesia which calculates the average stock price index for stocks that meet Sharia principles. Shares registered in JII consist of 30 shares whose membership shall be periodically reviewed based on the performance of transactions in the stock exchange (Umam, Ratnasari, \& Herianingrum, 2019). Third, The FTSE Bursa Malaysia Hijrah Shariah Index (Hijrah) has been designed to be used as a basis of Shariah-compliant investment products that meet the screening requirements of international Islamic investors. Companies in the index are screened by the Malaysian Securities Commission's, Shariah Advisory Council (SAC) and the leading global Shariah consultancy, Yasaar Ltd, against a clear set of guiding principles (Lean \& Parsva, 2012). Fourth, FTSE Bursa Malaysia EMAS (FTSE) that is listed on the main board of the Bursa Malaysia. It is an index for all the ordinary securities that qualified for the rules of eligibility, free-floating as well as liquidity (Chang, 2011; Lean \& Parsva, 2012).

\subsection{Multivariate Generalized Autoregressive Conditional Heteroscedasticity}

In order to model co-movements of financial assets' returns and risk, a nonlinear model namely MGARCH or Multivariate Generalized Autoregressive Conditional Heteroscedasticity would be used in this research. Bauwens,
Laurent, and Rombouts (2006) mention that the MGARCH model is widely accepted for estimating financial volatility moving together across markets and times, especially studies of the relationship between volatility and the co-volatility of several markets. This means that we need to apply a proper methodology in order to take it into account. GARCH model can be expressed as following:

$\sigma_{i t}^{2}=\omega_{k}+\sum_{k=1}^{p} \alpha 2_{i k} \cdot f_{i, t-k}^{2}+\sum_{k=1}^{q} \beta_{i k} \cdot a_{i, t-k}^{2} \rightarrow i=1, \ldots, k$

where $\sigma_{k t}$ is defined as a univariate $\operatorname{GARCH}(1,1)$ model. The persistence of the conditional variance in (1) is measured by $\sum_{k=1}^{2}=\left(\alpha_{k}^{2}+\beta_{k}^{2}\right)$ and can also be interpreted as common persistence. $n$ other words, the dynamics of the elements of $H_{t}$ are the same.

$$
H_{t}=\Omega^{*}+\lambda_{1} \lambda_{1}^{1} \sigma_{1, t}^{2}+\lambda_{2} \lambda_{2}^{1} \sigma_{2, t}^{2}
$$

where $\Omega^{*}=\Omega-\lambda_{1} \lambda_{1}^{\prime} \omega_{1}-\lambda_{2} \lambda_{2}^{\prime} \omega_{2}$. Note that $E_{t-1}\left(f_{1 t} f_{2 t}\right)$ $=\omega_{1}^{\prime} \Omega w_{2}$ because $\omega_{k}^{\prime} \lambda_{l}=0$ for $k \neq l$. This implies that in the case of more than one factor we have the result that any pair of factors has a time-invariant conditional covariance.

According to Abduh (2020), GARCH model is widely used to deal with time series heteroscedastic models to provide a volatility measure, which can be useful to take financial decisions. There are two purposes of analyzing volatility, namely to understand and explain its cause within a period of time. MGARCH model in this study is to gauge the volatility of risk and returns from both Islamic and conventional markets. Before using the MGARCH (Multivariate Generalized Autoregressive Conditional Heteroscedasticity) method it is necessary to check whether an MGARCH effect on the model residues. LM test and the Wald test are the two standard approaches to constructing test statistics for parametric hypotheses.

In financial data analysis, the detection of GARCH effects can use the Lagrange Multiplier (LM) test (Gel \& Chen, 2012). One of the important steps before applying GARCH methodology is to examine the residual of risk and return for evidence of heteroscedasticity. The test is based on decomposing the GARCH model multiplicatively into two components, one of which represents the null hypothesis, whereas the other one rejects the null hypothesis (Catani, Terasvirta, \& Yin, 2017).

Next stepis performed by examining the existence of relationships between parameter groups from the MGARCH model. According to Kafou and Chakir (2015), the Wald test is the suitable tool to analysis the relationship of two or more variables The relationship between the parameters of two variables makes it possible to express one variable in another, thus simplifying the model and increasing degrees of freedom. Wald test is to determine whether or not, a set of 
time series data is useful in forecasting another set of data or to determine the relationship between two or more subsets of variables. Wald test starts from presuming a particular parametric structure of the underlying multivariate volatility process Hafner and Herwartz (2008). A value of probability or significance which is less than $0.05(\leq 0.05)$ indicates a relationship between the independent variable $(\mathrm{X})$ and the dependent variable (Y) individually or partially. If the probability or significance is $\geq 0.05$, there is no relationship between independent variable (X) with dependent (Y) partially or individually

In a multivariate GARCH (p,q) model, conditional variance and covariance of each asset depend upon not only on its own past conditional variance and past squared innovations, but also on the stream squared innovations and current conditional variances of the other assets (Acatrinei, Gorun, \& Marcu, 2013). The routine of the t-DCC estimation:

[1]. Estimate multivariate GARCH models (assuming normal and ' $t$ ' distributions)

[2]. Estimate unconditional volatilities and correlations

[3]. Plot the estimated conditional volatilities and correlations

[4]. Test 'mean reversion' of volatilities

[5]. Forecast conditional volatilities and correlations

[6]. Estimate multivariate GARCH is applied to a set of OLS residuals.

\section{Result and Discussion}

The resultant time series for each index is then used to plot on graphs and is used to produce descriptive statistics that are reported in Table 1. Descriptive statistics can be used as an initial description of the attributes of the time series in terms of mean and standard deviation. Furthermore, the correlation will be calculated in order to estimate the strength and direction relationship of GCC Islamic index with its conventional GCC counterparts and are reported in Table 2. Besides descriptive statistics, the log returns are plotted on graphs in Figure 1 showing the volatility clusters.

We take data from four different markets, namely FTSE, JII, JCI and Hijrah. It is daily data with length is from April 2012 to April 2020 and the total data is 1952 using MGARCH $t$-DCC. Based on Standard Deviation, it is found that JII is the most volatile, followed by JCI, FTSE Hijrah, FTSE as the less volatile index. From the above ML Estimates of the t-DCC model on stock market indices, we observe that most return volatility estimates are statistically significant and near to unity. This finding implies most parameters of the model experience gradual decay in volatility under t-DCC model as well. The maximized log likelihood value (639.6642) under t-DCC model. The estimated degrees of freedom is 3.090843 , well below the value of 30 . These conclusions are robust to the way returns are standardized for computation of cross asset return correlations.

Table 1: Multivariate GARCH with Underlying Multivariate t-distribution Converged After Iterations

\begin{tabular}{|l|c|c|c|c|}
\hline nParameter & Coefficient & Std. Deviation & t-Stat & p-value \\
\hline Lambda_FTSE & -0.01224 & 0.002073 & -5.90645 & $0.0000^{*}$ \\
\hline Lambda_JII & 0.002614 & 0.005196 & 0.503158 & 0.6149 \\
\hline Lambda_HJR & -0.0135 & 0.002583 & -5.2258 & $0.0000^{*}$ \\
\hline Lambda_JCI & 0.006484 & 0.004237 & 1.530108 & 0.126 \\
\hline Delta & 0.000256 & 0.000103 & 2.479382 & $0.0132^{*}$ \\
\hline Df & 3.090843 & 0.221247 & 13.97013 & $0.0000^{*}$ \\
\hline Maximized Log-Likelihood = 639.6642 & & \\
\hline \multicolumn{2}{l|}{ df is the degrees of freedom of the multivariate t distribution } \\
\hline
\end{tabular}

* denotes significance at $95 \%$ level of significance

Table 2: Estimated Time-Varying Conditional Volatilities and Correlations Volatility Matrix

\begin{tabular}{|l|c|c|c|c|}
\hline & JCI & JII & FTSEHJR & FTSE \\
\hline JCI & 1 & 0.925965 & 0.043237 & 0.045187 \\
\hline JII & 0.925965 & 1 & 0.032295 & 0.034226 \\
\hline FTSEHJR & 0.043237 & 0.032295 & 1 & 0.963254 \\
\hline FTSE & 0.045187 & 0.034226 & 0.963254 & 1 \\
\hline \multicolumn{2}{|l}{ For the time -varying conditional Volatilities and correlations see the Post Estimation Menu } \\
\hline
\end{tabular}


The observation of market performance must also consider the correlation among indices. The following table shows correlation matrix among variables in this study. Table 1 shows that Malaysian indices have dynamic but negative correlations at $95 \%$ level of significance. Malaysia market more dynamic both conventional and Islamic on the figure 1. This case does not found in Indonesian market, between Islamic and composite was not significant.

A positive correlation shows a linear or unidirectional relationship whereas a negative version shows a contradictory relationship. In the figure shown at intervals of -1 and 1 . The correlation between variables is stated then stops from the number 1. According to Rusmita, Muharam, Rani, and Cahyono (2020), If the correlation was negative, investors could make portfolio between the Islamic and conventional but they could not completely eliminate this portfolio risk. From the above result, the index specific estimates of the volatility and correlation decay parameters. In Indonesia, JCI has strong correlation with JII at 0.925965 . However, similar case is found in Malaysia where FTSE has strong correlation with its Islamic counterpart (FTSE Hijrah) at 0.963254.

The some implication from above findings is that, before investing in Islamic stocks, Indonesian capital market investors must look closely to the Jakarta Composite Index (JCI). This is because the two indices are strongly correlated, while the Islamic market in Indonesia follows the movement of the conventional capital market. Investor will not have a good diversification in selecting the portfolio if Islamic and conventional stock markets have no good diversification. It was in line with previous study by (Pranata \& Nurzanah, 2015) that stated Islamic index was less volatility than conventional and the movement of Islamic index is follow the market consist all of stock. The lower volatility compared to Non-JII (Sharia and Non-Sharia) it was consisting with theory that stated blue-chip stock that have low leverage almost have good stability in the performance return of stock. Listyaningsih and Krishnamurti (2016) also mention JII stock consist of Islamic stocks which have high market capitalization, high liquidity, and low leverage, causing the low volatility of the Islamic index.
For the Malaysian case, since the composite/conventional FTSE Emas and the Islamic FTSE Hijrah are strong correlated (0.963254), analysis on the behavior of the Islamic index can be predicted by merely looking into the conventional index movement. The high correlation between conventional and Islamic is important for investor due to diversification proposes. According to Nazlioglu, Soytas, and Gupta (2015) sharia stock have similar volatility transmission pattern volatility and outperforming from conventional index. This result was contrary with by Umirah and Masih (2017) that is sharia stock index have low correlation with another index regardless conventional and Islamic. The volatility between Islamic and conventional index in Malaysia also different with previous study that Islamic is less volatility than conventional.

Investor from Malaysia or overseas whose interest with sharia index only, they could consider sharia index from Malaysia and also sharia index from Indonesia because on table 2 shows low correlation between sharia index Indonesia and Malaysia (0.032295). The following table depicts the mean reversion based on the Wald test estimation.

Table 3 reveal some important results that will be used in identifying whether crisis affects on Islamic and Conventional stock indices. Shock condition will probably effected FTSE Emas in p-value 0.002073 or $0.2 \%$ it is significant in 5\%. Meanwhile, shock will affect to Islamic HJR significant in $5 \%$ with p-value 0.005196 or $0.5 \%$, so it can be concluded that Islamic is more sensitive than conventional index. According to Lean and Parsva (2012), a fall in economic status can indicate a high risk of the Islamic stock index against FTSE Malaysia in the midst of a crisis, compared to the normal period. The results show that, at 5\% significance, the JCI has a p-value of $0.2583 \%$ while the JII is $0.4237 \%$. This shows different result from the Malaysia stock market. In Indonesia JCI is more sensitive in the market, compare to JII, it was consistent with Listyaningsih and Krishnamurti (2016) and Sukmana and Kolid (2012) that mention JII have a good liquidity and performance in the crisis because JII is the blue chip stock and have low leverage.

Table 3: Mean Reversion

Wald test of restriction (s) imposed on parameters

\begin{tabular}{|l|c|c|c|}
\hline $\begin{array}{l}\text { List of restriction (s) for } \\
\text { the Wald test : }\end{array}$ & Wald Statistic (chi-square) & p-value & \\
\hline $0=1$ - LAMBDA_FTSE & -1.01224 & 0.002073 & Mean Reverting \\
\hline $0=1$ - LAMBDA_HJR & -0.99739 & 0.005196 & Mean Reverting \\
\hline $0=1$ - LAMBDA_JII & -1.0135 & 0.002583 & Mean Reverting \\
\hline $0=1$ - LAMBDA_JCI & -0.99352 & 0.004237 & Mean Reverting \\
\hline
\end{tabular}


Above table shows that all stock indices show mean reversion, which signifies that the overall performance of all stock indices would be likely to return to its long-run mean. In other words, if shocks occur in the observed market, the market may not have differed greatly from the past average. This also implies that investors in these markets take into account the historical return on their investment decision. This result was also similar with Umirah and Masih (2017) that mention, if shock in sharia index Malaysia and other index in the overseas is not permanent. It was indicated that investor and investment manager who want to generate profit on investments better to allocate assets in the long run. If the investor and manager investment are herding on the shock and follow short run investment decisions may possibly get to get low returns or even losses.

To check model validity, Lagrange Multiplier (LM) test is conducted. The result of the LM test is shown on the following table:

Table 4: LM Test Result

\begin{tabular}{|c|c|c|c|c|}
\hline Regressor & Coefficient & Standard Error & T-Ratio & P-value \\
\hline OLS RES (-1) & -0.01374 & 0.117839 & -0.11658 & 0.9075 \\
\hline OLS RES (-2) & 0.121859 & 0.116968 & 1.041817 & 0.301 \\
\hline OLS RES (-3) & 0.007827 & 0.11697 & 0.066912 & 0.9468 \\
\hline OLS RES (-4) & -0.01144 & 0.117836 & -0.09708 & 0.9229 \\
\hline \multicolumn{2}{|c|}{ Langrange Multiplier Statistic } & $\mathrm{CHSQ}(4)=$ & 1.175369 & 0.8821 \\
\hline \multicolumn{2}{|c|}{ F Statistic } & $\mathrm{F}(4,72)=$ & 0.279021 & 0.8906 \\
\hline
\end{tabular}

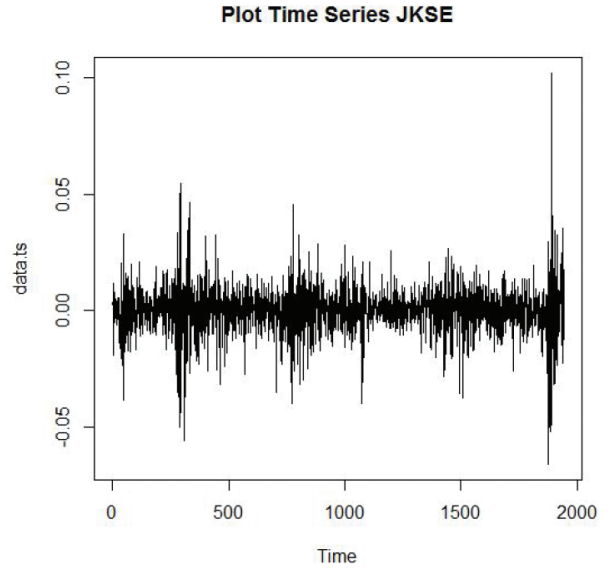

Plot Time Series FTSE

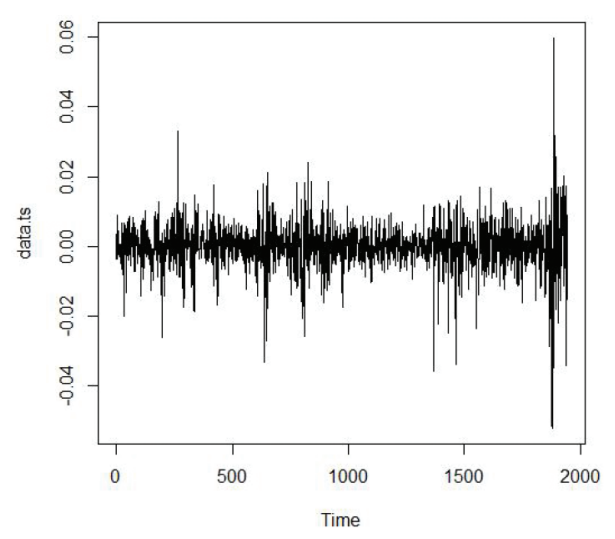

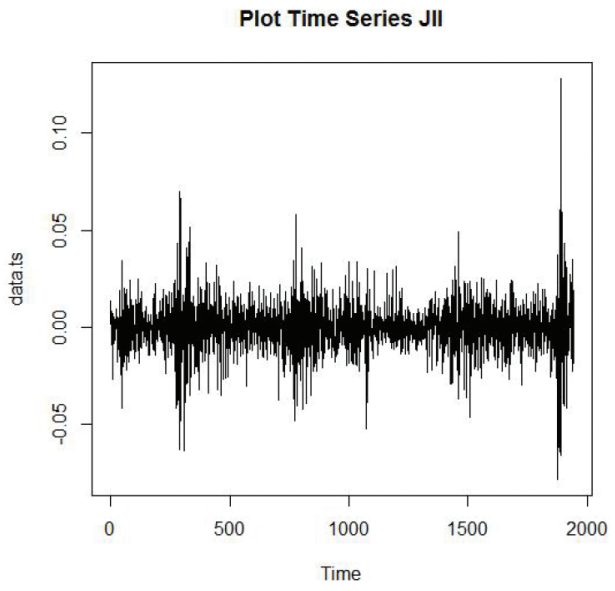

Plot Time Series FTSE HIJRAH

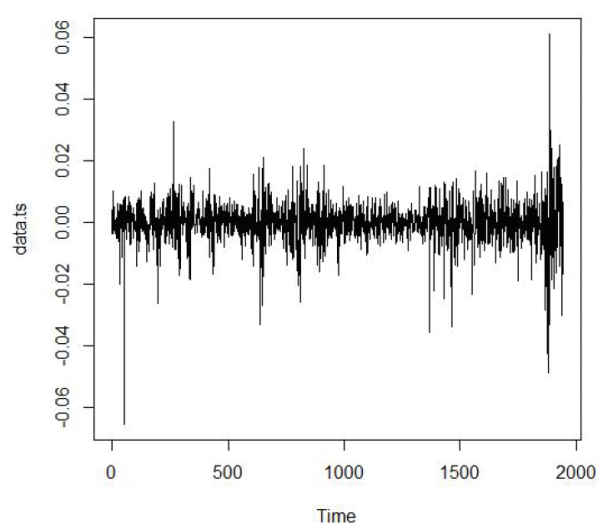

Figure 1: Weekly Return 
The above table shows that the LM test stastic is equal to 0.279 with p-value of 0.8906 . This means the LM test is not statistically significant and we cannot reject our null hypothesis. In other words, t-DCC model is correctly specified.

Based on the Figure 1 in the last time period show that there is shock in the market both in Malaysia and Indonesia, the data shows high volatility movement. The volatility of capital market reflects the future information about market return and risk. Figure 1 illustrates that the risk is very high which is followed by an increase in returns. The latest data was taken when the capital market crisis occurred due to Covid-19, namely from January to April 2020. Investors' perceptions about industry shutting down due to the virus caused huge losses and raised market distress. Previous research, such as (Hong, 2016) has shown that overloading assumptions stave off stock prices from reflecting their intrinsic value, resulting in deadweight losses for investors due to misallocation of investment in the less productive industries.

Therefore, the effectiveness of policies is very important to the development of the capital market in the Emerging Market and becomes a challenge to reform policies related to the handling of the capital market during pandemic. Figure 1 informs that after high fluctuation, the graph shows that volatility has begun to normal. This condition indicates that there is an effective policy to reduce the market distress, then immediately revert the stock price into the equilibrium level.

Based on the results and analysis above, investors and investment managers need to choose different portfolios in order to get the best portfolio. Islamic indexes could be the best choice for portfolio investment. The suggestion for investors can be that the best portfolio can be arranged from various types of indexes and they should consider choosing an index that is not too correlated. The portfolio investment, it could be mixed with overseas indexes such as JII and HJR that are not highly correlated, also avoid portfolios that have high correlation such as JCI and JII. Second, during a crisis, all indexes in Indonesia and Malaysia will experience a shock, whether it is Islamic or conventional. Therefore, investment based on Islamic principles, as mentioned by Romli, Mohammad, and Yusof (2012), is to ignore speculations because rapid buying and selling in the market will not be beneficial to enhance Muslim investors' economy, so in term of crisis, this paper suggests to invest for the long run, because once the condition gets better, it will not be much different from the normal condition.

\section{Conclusion}

The purpose of this paper is to find the relationship between Islamic and conventional stock markets in Indonesia and Malaysia. In addition, this paper aims to determine the best place to invest between conventional and
Islamic stock markets, both regionally and internationally, in order to obtain portfolio diversification benefits. The results showed that the Islamic stock market in both countries has a strong correlation with the conventional stock market; Jakarta Composite Index with the Jakarta Islamic Index and FTSE Gold with the FTSE Hijrah Index. This indicates that the investment made regionally on the Islamic and conventional stock markets of the two countries can yield benefits. However, internationally, Indonesia and Malaysia composite and Islamic is low-correlated, meaning that the diversification portfolio does not provide high benefits. This also happened during the crisis. Both indices in both countries cannot provide a good amount of benefits to the investors. In general, the results of this study supports the previous empirical literature whereby stock market tends to have strong correlation during crisis period, which will decrease the portfolio diversification benefit. Empirical studies on the volatility of the capital market need to be improved, especially in countries that run sharia and conventional systems in their capital markets. Information about the volatility of the capital market is very useful for investors and investment management to make feasible and profitable investment decisions. An Islamic capital market also could be a consideration place to invest because it provides the best portfolio and is less risky.

\section{References}

Abduh, M. (2020). Volatility of Malaysian conventional and Islamic indices: does financial crisis matter? Journal of Islamic Accounting and Business Research, 11(1), 1-11. https://doi. org/10.1108/JIABR-07-2017-0103

Acatrinei, M., Gorun, A., \& Marcu, N. (2013). A Dcc-Garch Model to Estimate. Romanian Journal of Economic Forecasting, 16(1), 136-148.

Ajmi, A. N., Hammoudeh, S., Nguyen, D. K., \& Sarafrazi, S. (2014). How strong are the causal relationships between Islamic stock markets and conventional financial systems? Evidence from linear and nonlinear tests. Journal of International Financial Markets, Institutions and Money, 28(1), 213-227. https://doi. org/10.1016/j.intfin.2013.11.004

Al-Khazali, O., Lean, H. H., \& Samet, A. (2014). Do Islamic stock indexes outperform conventional stock indexes? A stochastic dominance approach. Pacific Basin Finance Journal, 28, 2946. https://doi.org/10.1016/j.pacfin.2013.09.003

Alexander, G. J., \& Baptista, A. M. (2003). Portfolio performance evaluation using value at risk. The Journal of Portfolio Management, 29(4), 93-102.

Bauwens, L., Laurent, S., \& Rombouts, J. V. (2006). Multivariate GARCH models: a survey. Journal of Applied Econometrics, 21(1), 79-109. https://doi.org/10.1002/jae.842

CAMBA, A. C. (2020). Capturing the Short-run and Long-run Causal Behavior of Philippine Stock Market Volatility under 
Vector Error Correction Environment. The Journal of Asian Finance, Economics and Business, 7(8), 41-49. https://doi. org/10.13106/jafeb.2020.vol7.no8.041

Catani, P., Teräsvirta, T., \& Yin, M. (2017). A Lagrange multiplier test for testing the adequacy of constant conditional correlation GARCH model. Econometric Reviews, 36(6-9), 599-621. https://doi.org/10.1080/07474938.2017.1307311

Chang, D. (2011). Testing some of Benjamin Graham's stock selection criteria: A case of the FTSE Bursa Malaysia EMAS Index from Year 2000 to 2009. Jurnal Manajemen Dan Kewirausahaan, 13(2), 99-106. https://doi.org/10.9744/ jmk.13.2.99-106

Dewandaru, G., Rizvi, S. A. R., Masih, R., Masih, M., \& Alhabshi, S. O. (2014). Stock market co-movements: Islamic versus conventional equity indices with multi-timescales analysis. Economic Systems, 38(4), 553-571.

Fama, E. F. (2017). The Fama Portfolio: Selected Papers of Eugene F. Fama (J. H. Cochrane \& T. J. Moskowitz (eds.)). The University of Chicago Press. https://doi.org/10.7208/ chicago/9780226426983.001.0001

Gel, Y. R., \& Chen, B. (2012). Robust Lagrange multiplier test for detecting ARCH/GARCH effect using permutation and bootstrap. Canadian Journal of Statistics, 40(3), 405-426. https://doi.org/10.1002/cjs.11149

Gencay, R., Selcuk, F., \& Whitcher, B. (2001). Differentiating intraday seasonalities through wavelet multi-scaling. Physica A, 289, 543-556.

Gumanti, T. A. (2011). Investment Management: Concept, Theory, and Application. Mitra Wacana Media.

Hafner, C. M., \& Herwartz, H. (2008). Testing for causality in variance using multivariate GARCH models. Annales d'Economie et de Statistique, 89, 215--241. https://doi. org/10.2307/27715168

Hong, H. (2016). Information Cascade and Share Market Volatility: A Chinese Perspective. The Journal of Asian Finance, Economics and Business, 3(4), 17-24. https://doi.org/10.13106/ jafeb.2016.vol3.no4.17

In, F., \& Kim, S. (2013). An introduction to wavelet theory in finance. World Scientific Publishing.

Kafou, A., \& Chakir, A. (2015). The Day of the Week Effect on Islamic Stock Market Returns: Evidence from Dow Jones Islamic Market Index. Journal of Islamic Economics Banking and Finance, 11(3), 25-46. https://doi.org/https://doi. org/10.12816/0024439

Kamil, M., Kamil, N., Bacha, Ismath, O., Masih, M., \& Mansur, A. (2012). Do ' Sin Stocks ' Deprive Islamic Stock Portfolios of Diversification? Some Insights from the Use of MGARCHDCC. Capital Markets Review, 1(1), 43-64.

Karim, B. A., Majid, M. S. A., Isa, A. H. M., \& Jais, M. (2010). Capital control and stock market integration. Proceedings of 2010 Oxford Business \& Economics Conference Program.

Lean, H. H., \& Parsva, P. (2012). Performance of Islamic indices in Malaysia FTSE market: Empirical evidence from CAPM.
Journal of Applied Sciences, 12(12), 1274-1281. https://doi. org/10.3923/jas.2012.1274.1281

Listyaningsih, E., \& Krishnamurti, C. (2016). How is The Volatility of Jakarta Islamic Index Stocks? Jurnal Bisnis Dan Manajemen, 17(2), 109-122. https://doi.org/10.24198/jbm.v17i2.25

Nazlioglu, S., Soytas, U., \& Gupta, R. (2015). Oil prices and financial stress: A volatility spillover analysis. Energy Policy, 82(1), 278-288. https://doi.org/10.1016/j.enpol.2015.01.003

Omar, A., Abduh, M., \& Sukmana, R. (2013). Fundamentals of Islamic money and capital markets. John Wiley \& Sons.

Pranata, N., \& Nurzanah. (2015). Conventional and Islamic indices in Indonesia: A Comparison on Performance, Volatility, and the Determinants. Indonesian Capital Market Review, 7(2), 113127. https://doi.org/10.21002/icmr.v7i2.5004

Rahmi, M., Azma, N., Muttaqin, A. A., Jazil, T., \& Rahman, M. (2016). Risk Volatility Measurement: Evidence from Indonesian Stock Market. The Journal of Asian Finance, Economics and Business, 3(3), 57-65. https://doi.org/10.13106/jafeb.2016. vol3.no3.57.

Romli, N., Mohamad, A. A. S., \& Yusof, M. F. M. (2012). Volatility analysis of FTSE Bursa Malaysia: Study of the problems of Islamic stock market speculation in the period 2007 to 2010. African Journal of Business Management, 6(29), 8490-8495. https://doi.org/10.5897/AJBM11.1049

Rusmita, S. A., Muharam, I. N., Rani, L. N., \& Cahyono, E. F. (2020). Dynamics relationship between the composite and Islamic index in the capital market of Indonesia. Advances in Business, Management and Entrepreneurship, 442-448. https://doi.org/10.1201/9780429295348-96

Rusmita, S. A., Salleh, M. C. M., Sukmaningrum, P. S., \& Zulaikha, S. (2019). Growth and Value Effect on Jakarta Islamic Index: Analysis towards Performance of Sharia Equity Mutual Fund. Al-Iqtishad: Jurnal Ilmu Ekonomi Syariah, 11(1), 153-165. https://doi.org/10.15408/aiq.v11i1.9670

Saiti, B., Bacha, O. I., \& Masih, M. (2014). The diversification benefits from Islamic investment during the financial turmoil: The case for the US-based equity investors. Borsa Istanbul Review, 14(4), 196-211. https://doi.org/10.1016/j. bir.2014.08.002

Sukmana, R., \& Kolid, M. (2012). Impact of global financial crisis on Islamic and conventional stocks in emerging market: an application of ARCH and GARCH method. Asian Academy of Management Journal of Accounting $\mid \&$ Finance, 31(2), 357-370.

Tamakoshi, G., \& Hamori, S. (2014). Co-movements among major European exchange rates: A multivariate time-varying asymmetric approach. International Review of Economics and Finance, 31, 105-113. https://doi.org/10.1016/j. iref.2014.01.016

Uddin, G. S., Arouri, M. E. H., \& Tiwari, A. K. (2013). CoMovements between Germany and International Stock Markets: Some New Evidence from DCC-GARCH and Wavelet Approaches. SSRN Electronic Journal. https://doi. org/10.2139/ssrn.2311724 
Umam, A. K., Ratnasari, R. T., \& Herianingrum, S. (2019). The Effect Of Macroeconomic Variables in Predicting Indonesian Sharia Stock Index. Jurnal Ekonomi Dan Bisnis Islam, 5(2), 223-240. https://doi.org/10.20473/jebis.v5i2.15031

Umirah, F., \& Masih, M. (2017). Should the Malaysian Islamic stock market investors invest in regional and international equity market to gain portfolio diversification benefits?
Munich Personal RePEc Archive No. 79762. https://mpra. ub.uni-muenchen.de/id/eprint/79762

Worthington, A., \& Higgs, H. (2004). Transmission of equity returns and volatility in Asian developed and emerging markets: a multivariate GARCH analysis. International Journal of Finance \& Economics, 9(1), 71-80. https://doi.org/10.1002/ ijfe. 222 